\title{
RE-READING HATTA'S THINKING IN MOVEMENT: BETWEEN ISLAM AND NATIONALISM
}

\author{
Rian Wahyudin \\ UIN Syarif Hidayatullah Jakarta, Indonesia \\ E-mail: rianwahyuddin@gmail.com
}

\begin{abstract}
This article reviews the perspectives of Mohammad Hatta as one of the Indonesian founding fathers in regards between Islam and nationalism. Many scholars, historians, and intellectuals have deemed that Hatta was a secular nationalist who separated national propositions from religious values. Whereas, on the contrary, both his actions and thoughts were in line with the noble of Islamic values, not only when he wanted to establish the Indonesian Islamic Democratic Party in 1967 with several other activists such as alumni of Islamic Students Association (HMI), PII, the Indonesian Islamic Syarikat Party, and Nahdlatul Ulama (NU) figures, but also Hatta's Islamic integrity already seen during the movement, when he was active in both the Indonesian Association (PI) organization in 1921-1930 and the Indonesian National Education (PNI Baru) in 1931-1932. For instance, Hatta proposed his thoughts on peace, which he took from Qur'an surah al-Fatihah verse two. According to him, the concept of peace is the highest law in Islam; therefore, every free nation must uphold peace. He continued, the statement "God is the Most Gracious and Most Merciful" must be applied to create security and convenience among human beings. In February 1927, while serving as the administrator of the Indonesian Association in the Netherlands, Hatta and Nazir Pamontjak, Ahmad Subardjo, Gatot Tarumihardja, and Abdul Manaf were serving as the administrator of the Indonesian Association became delegators at the presidium meeting "Congress Against Imperialism and Colonial Oppression." This event was organized by the "League Against Imperialism and for National Independence" in Brussels, Belgium. There Hatta and his fellows sat on a par with delegates from other countries such as Chen Kuen and Liau Hansen (China), Roger Baldwin (United States), Jawaharlal Nehru (India), Willi Munzenberg and Georg Ledebour (Germany), and several delegates from France, Belgium, Latin America, England, and Czechoslovakia to oppose all forms of oppression and demand the independence of Indonesia and other occupied countries to achieve world peace. Moreover, the identity of Mohammad Hatta is known well as a figure who came from a family of wellknown merchants and scholars in Minang, coupled with his expertise in associating with nationalist figures, made Islamic integrity not appeared by attributive religious symbols, but rather by his behavior, thoughts, and attitudes in everyday life.
\end{abstract}

Keywords: bung hatta; islam; nationalism; movement period

Abstrak. Artikel ini mengulas tentang pemikiran salah satu bapak bangsa, Mohammad Hatta mengenai hubungan antara Islam dan nasonalisme. Banyak Sarjana, Sejarawan dan Cendikiawan masih menganggap bahwa Bung Hatta adalah seorang nasionalis sekuler, memisahkan soal-soal kebangsaan dari ajaran agama. Tindak-tanduk bahkan pemikirannya malah sejurus dengan nilainilai luhur Islam, bukan hanya saat dirinya dan beberapa aktivis lain seperti alumni HMI, PII, Partai Syarikat Islam Indonesia dan tokoh NU yang hendak mendirikan Partai Demokrasi Islam Indonesia pada tahun 1967, keberislaman Bung Hatta justru sudah terlihat pada masa pergerakan baik saat aktif di organisasi Perhimpunan Indonesia (PI) tahun 1921-1930 maupun di Pendidikan Nasional Indonesia (PNI Baru) tahun 1931-1932. Pemikirannya tentang perdamaian misalnya Hatta justru mengambilnya dari Surat al-Fatihah ayat dua. Konsep damai menurutnya hukum yang paling tinggi dalam Islam, oleh karenanya tiap-tiap bangsa yang merdeka harus menjunjung tinggi perdamaian. Menurutnya, "Allah yang Maha Pengasih dan Maha Penyanyang" itu harus diamalkan agar tercipta keamanan dan kenyamanan antar sesama umat manusia. Pada bulan Februari 1927 saat menjadi pengurus Perhimpunan Indonesia di Belanda, Bung Hatta bersama Nazir Pamontjak, Ahmad Subardjo, Gatot Tarumihardja dan Abdul Manaf menjadi delegator pada rapat presidium "Kongres Menentang Imperialisme dan Penindasan Kolonial". Kegiatan ini diselenggarakan oleh "Liga Menentang Imperialisme dan untuk Kemerdekaan nasional" di Brussel, Belgia. Di sana Hatta dan kawan-kawan duduk sejajar dengan delegator dari negara lain seperti Chen Kuen dan Liau Hansin, (China), Roger Baldwin (Amerika Serikat), Jawaharlal Nehru (India), Willi Munzenberg dan Georg Ledebour (Jerman), dan beberapa utusan lain dari Prancis, Belgia, Amerika Latin, Inggris dan Cekoslovakia untuk menentang segala bentuk penindasan dan menuntut kemerdekaan negara Indonesia dan negara lainnya yang sedang dijajah agar terwujudnya perdamaian dunia. Jati diri Bung Hatta yang berasal dari keluarga saudagar dan ulama masyhur di Ranah Minang ditambah dengan kepiawaiannya dalam bergaul dengan tokoh-tokoh nasionalis membuat corak keberislaman Hatta tidak ditonjolkan dengan simbol-simbol agama yang atributif, melainkan ditonjolkan dengan tingkah laku, pemikiran dan sikap dalam kehidupan sehari-hari.

Kata Kunci: Bung Hatta; Islam; Nasionalisme; Masa Pergerakan

Permalink/DOI: https://doi.org/10.15408/mimbar.v38i1.21005 


\section{Introduction}

The concepts of socialization and nationalism proposed by MC Turnan Kahin were utilized in this article. Socialization is the entire process in which an individual, from childhood to adulthood, grows, interacts, knows, and adapts to the individuals living around to shape personality, behavior, and thoughts (Imam Subchi, 2012). Socialization is the process of individuals learning to know and understand which behaviors to do and which behaviors not to do ( $\mathrm{D}$ Dwi Narwoko and Bagong Suyanto, 2015). A person's character, personality, and thoughts are shaped through this socialization process, including Mohammad Hatta's thoughts, who lived in religious and Western cultures.

The urgency of adopting the Sociological approach is in line with the life of Hatta, who is part of the Sumatran Merchant and Religious figures who adhere to Islamic teachings. On the other hand, Hatta is a student activist in the Netherlands, and the educational atmosphere is lots of turmoil in Western ideas. These two cultural influences formed Hatta as a nationalist activist as well as a religious activist. Therefore, to investigate the remnants of Hatta's ideas, the author adopts a Sociological method in this present article.

According to Kahin, through his nationalism theory, Islam does not passively absorb the impulses from the original concept of nationalism. Instead, it offered the earliest conduit for forming modern and mature nationalism for Indonesian, a channel that continues to play a significant role. The unique ideology of Islam, which is accepted by almost 90 percent of Indonesian people, has made it feasible. In addition, Kahin believes that Islam in Indonesia is tolerant, avoiding extremism and radicalism, as is frequently the case in other areas of Islam, such as in the Middle East (George Mc Turnan Kahin, 2013). (George Mc Turnan Kahin, 2013).

Nationalism found its form in the Dutch East Indies for it was not contradictory to Islamic teachings even then when Indonesia was attacked again by the Dutch and British in 1945, Nahdlatul Ulama (NU), as a representation of the majority of Muslims, gave a fatwa that loving the homeland (patriotism) is part of faith. From this, we may conclude that an inclusive religious spirit fosters the growth of nationalism.

This fact is likewise following Azyumardi Azra's idea of nationality. According to Azra, the nationalism that emerged in Indonesia is a mix of ethnic and political emotions which later fused with religious spirit (Azyumardi, 2006). This is also what Azyumardi subsequently believed that Southeast Asian Islam, particularly Indonesia, with a tolerant and friendly image, gave stimulation, developed, and even played a decent role in the development of nationalism.

In 1932, Hatta classified nationalism into three categories with his book "Towards an Independent Indonesia." To begin, there is aristocratic nationalism (Cap Ningrat), which evaluates patriotism in terms of one's class. Second, the nationalist concept of the intellectual (Cap Intelek) suggests that if Indonesia achieves independence in the future, intellectuals would be given preference for leadership. Third, nationalism of the people (Cap Rakyat) suggests that a country's excellence will be determined in part by the quality of its people (Salman Alfarisi, 2012). Hatta's initial concept of nationalism was the nationalism of people. According to Hatta, the people are the primary determinant of a nation's development and demise. According to this definition, Mohammad Hatta's idea of 
nationalism of the people category is a thought that is rich in Islamic principles since Hatta never dichotomy of the national narrative with the teachings of Islam.

The nationalism of the people (Cap Rakyat) is Hatta's original idea which is grounded on the Islamic spirit. Hatta believed that the nationalism of the people meant that when Indonesia became independent, the state must be established on the sovereignty of the people. This sovereignty notion is the foundation for all varieties of civilized human beings (Mohammad Hatta, 1976). Hatta idealized that civility was the first asset and the primary basis in establishing the state order and felt when Indonesia got independence.

\section{Biography of Mohammad Hatta}

Mohammad Hatta was born with the original name Muhammad Athar. This name is taken from the name of an Islamic figure, namely Ahmad Ibn Muhammad Ibn Abdul Karim Ibn Ata Ilah Al Sakandari, the author of the book Al-Hikam (Salman Alfarizi, 2012). Hatta was born in Bukittinggi, West Sumatra, on August 12, 1902, from the womb of a mother named Siti Saleha. His father's name was Haji Muhammad Djamil, who came from the Batu Hampar area. From his father's line, Hatta is descended from a famous Islamic cleric, Muhammad Djamil (Hatta's father) is a son of Shaykh Abdurrahman (Hatta's grandfather), a leader of Surau Batu Hampar. Surau is a traditional Islamic educational institution developed in Minangkabau, which characteristically has similarities with Islamic boarding schools on the island of Java (Arif Subhan, 2009). The Surau, led by the Grandfather of Hatta at that time, was very attractive to people interested in studying religion, so it is not surprising that this Surau also became a centre for the study of religion Naqsbandiyyah Tariqa (Deliar Noer, 1990).

Meanwhile, from his mother's line, Hatta is a descendant of a merchant where the Grandma of Hatta from his mother's line has a trading business in his place of residence. In contrast, his husband (Hatta's grandfather) named Ilyas, has an extensive network in his trading business, including Sawahlunto and Lubuk Attitude. Regarding Hatta's mother, Deliar Noer stated that the origin of his mother originated from mixed blood or not from Minang people. Deliar Noer thought that she was from Java.

In his life, Hatta more often received attention from his mother's side family because, since the age of eight months, Hatta has been an orphan. Hatta's father died at the age of thirty. Even though he lived under the auspices of his mother, Hatta did not simply abandon the teachings he received from his father, as evidenced by when he was a child, Hatta studied Islamic religious knowledge at Surau Batu Hampar under the guidance of his paternal uncle, Haji Muhammad Djamil Djambek. Hatta learned the Qur'an from his uncle about Arabic grammatical and linguistics (Nahwu Sorof), Islamic Jurisprudence (Fiqh), and Exegesis of the Qur'an (Tafsir).

In Sociological theory, the nature of a person will be influenced by the environment in which he lives and settles, both in the geographical environment and in the cultural environment introduced by his family. Even with Hatta's personality, which from an early age was influenced by the natural environment of Minangkabau (Bukittinggi), which is geographically located in the highlands which has a strong tradition, it is different from the coastal plains, which are dominated by all corners of the 
country with solid religious nuances. This is in accordance with what Deliar Noer termed adat menurun syara mendaki. Minangkabau customs were introduced by Minang people who wanted to migrate abroad, while Preachers brought Islamic teachings outside to Minang land.

Beautiful lakes such as Maninjau, Singkarak, Diatas, and Dibawah lakes, and towering steep hills such as the Barisan hills that stretch along the island of Sumatra, the Merapi and Singgalang hills in Agam, the Sago hills in Limapuluh Koto, the Tandikat hills in Tanah Datar and the Ophir hills in Pasaman are simple descriptions of the geographical location of Minangkabau Land, especially the Bukittinggi area as a city where Hatta was born. According to Zubir Rasyad, such environmental conditions have placed Bukittinggi as the Struggle Town of all time. The name "Bukit Tinggi Koto" "Rang Agam" indicates that this location is the Koto (Fort) Nagari-Nagari Dubalang with red identity. The dominant geographical condition of Bukittinggi with hills made it possible for all Minangkabau residents to be safe from the influence of Dutch East Indies Colonialism, especially in the 19th century AD during the Padri War (Zubir Rasyad, 2009). Therefore, the thickness of Islamic culture and traditions in Bukittinggi can still be felt today without intervention (if it is not mentioned as a meeting between the three ideologies) by the Dutch Colonialism culture, including the personality of Hatta.

When he was a child, Hatta was faced with three notions that dominated the Minang people's lifestyle. The three understandings are tradition, Islamic teachings, and colonialism (Deliar Noer, 1990). Of these three notions, traditional understanding always dominates the pattern of life inherent in each individual, which is embodied in daily life but accepts the understanding of Colonialism, a form of necessity. The traditional leaders at that time established relations with the Dutch East Indies in their respective interests. The Dutch East Indies needed an intermediary to realize colonialization in Minangkabau by cooperating with several traditional leaders called Datuk as leaders of a Nagari. Meanwhile, some traditional leaders established relations with the colonialists to avoid threats to the Minangkabau Kingdom in the smallest area, namely Nagari.

The environment, dominated by religious nuances, has shaped Hatta's personality from time to time to become a religious person amid the struggles of several ongoing traditions. The provision of religious knowledge he obtained from Surau became the initial foundation in each of his movements. From his religious knowledge, Hatta relied upon all his movements solely for the sake of Allah (Mohammad Hatta, 1976).

\section{Formal and Non-formal Education}

Formal education is defined as a system that refers to educational programs launched by the government with predetermined regulations. Formal education has several levels ranging from elementary to tertiary levels. According to Arif Subhan (Arif Subhan, 2009), this formal education is a Colonial education project that began in the mid-19th century. Some Indonesian children from minimal circles have the opportunity to study in schools, while schools for European children have been built since 1816. Three decades later, the Dutch East Indies government opened schools for Indonesian natives.

As is well known, the Dutch East Indies administration in 1901 had an ethical-political agenda, one of which included educational programs. Even yet, the locals continue to feel the government's 
attitude, and the world of education is separated into social and racial groups comprised of Natives, Chinese, Arabs, and Europeans. The stratification system acknowledges the high-low level of society's divide, beginning with Europeans and continuing with the Foreign East (Arabs and Chinese), Indigenous Aristocrats (Priyayi), and ultimately the ordinary people (Nurcholis Madjid, 2003). The education levels range from elementary school through college. ELS (Europese Lagere School-European Primary School) is offered at the elementary school level for the European group. HAS (HollandsArabische School-Arabic Dutch School) and HCS (Hollands-Chinesche School-Chinese Dutch School) are offered for the Foreign East group. HIS (Hollands-Inlandse/School-Native Dutch Schools) is accessible to Priyayi or Indigenous Aristocratic communities. Finally, for the general public, there is Volkschool, the Village People's School, which offers a three-year learning program, and Vervolgschool, an advanced People's School, which offers a five-year study program at the District level.

Mohammad Hatta as an Indonesian child, received this formal education gradually and in stages up to Higher Education. At first, Hatta entered the People's School in 1908/1909 and then moved to ELS (same level as Elementary School) Bukittinggi until 1913. In grade 5, Hatta moved to ELS located in Padang until grade 7 in 1917. Hatta's shifting of schools from SR to ELS Bukittinggi and ELS Bukittinggi to ELS Padang is suspected because he chose a more modern quality of education, especially in language lessons. Furthermore, Hatta continued his secondary education at MULO (Meer Uitgebreid Lager Onderwijs) Padang from 1917 and finished in 1919. Hatta continued his education at PHS (Prins Hendrik Handels) in high school, located in Jakarta. The period of this study was completed from 1919-1921. Furthermore, Hatta explored higher education at the Handels Hoogere School, namely the high school of economics in Rotterdam, the Netherlands, in 1921, majoring in Trade Economics and graduating in 1932.

Regarding Hatta's gradual education informal education, there was something unique, as the Dutch East Indies government had previously determined that Indigenous people, both from the lower classes and Aristocrats (Priyayi), were to be educated exclusively in schools designed specifically for Indigenous people (Inlander School), such as the People's School, Volkschool, and at the Villa. It is, however, distinct from Hatta's educational route. Hatta spent two years at the People's School and the remainder of his education at non-native schools. In this instance, Hatta likely chose this educational route due to concerns about the quality of schooling. This is also the primary motivation for Hatta's mother's family to assist him in pursuing a higher degree in Rotterdam, the Netherlands. It should be emphasized that not all Indigenous peoples have access to an education tailored to the upper-middle class (East Asian - Arab and Chinese as well as European circles). Indigenous individuals who are allowed to attend top schools are expected to have a strong relationship with Dutch East Indies authorities and nobles (Suradi Hp et al., 1986). When seen through the lens of his ancestors, Hatta descended from a prominent Islamic figure family (on his father's side). Shaykh Abdurrahman, also known as Shaykh Nan Tuo, was the Grandfather of Hatta. He was a renowned scholar in Batu Hampar and also a leader of the Surau and Sufism communities.

Meanwhile, Hatta descended from a merchant family on his mother's side. Hatta's allegiance to the aristocracy may have been influenced by his stepfather, Mas Agus Haji Ning. Mas Agus Haji Ning is Hatta's stepfather. He is the son of Mas Agung Haji Akip, the owner of the Palembang port, and is the eighth descendent of the Palembang Prince of the Sidang Bajak (Deliar Noer, 1990). 
In addition to formal education, Hatta attended non-formal education in the form of religious education. The religious education that Hatta took was a recitation held in Surau while in Bukittinggi and Padang. In Bukittinggi, Hatta recited the Qur'an under the tutelage of Shaykh Haji Muhammad Djamil Djambek (1860-1947) with a concentration of Arabic subjects in the form of Nahwu and Sharaf as a tool to understand the subjects of Fiqh and Tafsir. Meanwhile, when he was in Padang, Hatta recited the Qur'an under the guidance of Haji Abdullah Ahmad, especially in 1918 with a concentration of Islamic religious lessons. Surau was the place where Hatta recited the Qur'an when he was still living in Bukittinggi. At first, Surau was a place of worship dedicated to the ancestors, but Surau underwent a process of Islamization over time. Its function became a place to seek religious knowledge even though the name remained Surau and became a symbol of Minangkabau customs (Azyumardi Azra, 2003). When he recited the Qur'an in Surau, in his Memoir Hatta explained as follows:

"In the morning, I used to go to school. In the evening after sunset, I learned to recite Qur'an at Surau Inyik Djambek. The basic teaching of Islam is to learn to recite by chanting it melodiously to instill religious feelings in the children's souls" (Mohammad Hatta, 1979).

It has been seen that Hatta, in the scientific context, has been luckier than his peers, who at that time could experience learning the Qur'an and going to school while his friends only recited the Qur'an. When Hatta's childhood was busy with school and religious lessons, while the lives of his friends were colored by the world of playing children their age, it was an irony that became part of Hatta's life experience at that time. However, because Hatta's family background is disciplined and prioritizes education, Hatta has enjoyed it and took it as a burden. "Most of my friends who are studying the Qur'an in Surau do not go to school. During the day they just play around or help their parents who work in the fields, herd buffalo and sell" (Mohammad Hatta, 1979).

\section{Hatta's Thoughts on Nationalism}

According to Mohammad Hatta, nationalism is the belief held by a large number of individuals that they are a nation. It shows awareness of their attachment as a nation (Deliar Noer, 1990). This definition was influenced by Lothrop Stoddard quoted by Hatta in his speech in Utrech in 1930, "Lothrop Stoddard defined nationalism is a belief, held by a bairly large number of individuals that they constitute a nationality, it is a sense of belonging together as a nation" (Nationalism is a belief that lives in the hearts of many people who come together as a nation) (Mohammad Hatta, 1976). Mohammad Hatta is a well-versed student in various subjects, an avid reader, and a participant in cross-national political activities. Therefore, it is unsurprising that world leaders significantly impact his opinions.

Hatta also quoted the opinion of Prof. Kranenburg on the concept of a nation. According to him, what becomes the criterion (measurement) of the nation is the realization as an alliance that is structured into one, namely the realization that arises because they believe in the equality of destiny and purpose. That realization is increased because of the same luck, and the same misfortune suffered, the same luck gained, because of the mutual merit, the misery, in short, because of the warning to the shared history that is embedded in the heart and brain. In this definition, Hatta asserts that they are destined to unite and live in the hearts of the Indonesian people, while this belief is getting stronger 
over time. Hatta also quoted Ernest Renan's opinion as a reference to the PI (Indonesian Association) principle of 1924, which said that the nation is one spirit, one inner principle, a shared feeling (PI Principles, 1924). Hatta concluded that in future independent Indonesia would become a unified nation and could not be divided.

According to Hatta, nationalism, especially that advocated by the PI, served as a bridge and complemented pre-existing movements in the Dutch East Indies, such as the communists and Muslims, in gaining Indonesian independence. Hatta underlined that nationalism does not require unity of origin, language, religion, or any other sort of unity (Hatta, 1976). This idea is consistent with Hatta's knowledge of the history of nation-building as demonstrated by Zsiterland and America, which have a diverse range of languages, ethnicities, customs, and religions, as well as customs, but are able to join. Thus, Hatta defined nationalism as the desire to unite. Hatta identified that the spirit of unity experienced by the Indonesian people first appeared in 1908 and 1912. That year was an essential historical beginning for the Indonesian nation.

"The years 1908 and 1912 marked as milestone moments in Indonesian history. Humanity's yearning desire for freedom began to resurface in the spirit of Indonesians in the twentieth century. A gentle light pierced the slaves' black night. Finally, after decades of servitude and submission, an early movement developed in Indonesian political life. The vision of an autonomous country begins to develop and take shape. National independence is ingrained in the minds and hearts of all Indonesian adolescents. No force can harm this bud; it is still alive and will not perish. It is doomed to flourish and will eventually become a symbol of national independence" (Hatta, 1924-1925).

That is how Hatta described Indonesian independence as a notion founded on the spirit of nationalism. According to Hatta, this spirit began with the creation of Budi Utomo (1908), Sarikat Islam (1912), and PI (1908). If Budi Utomo is limited to Javanese, Sundanese, and Madurese youth, his ideology remains national, even when combined with SI, founded in 1911 and had a sizable Muslim base. However, all communities came together to establish common objectives at the time. SI was the only national organization at the time with a large membership dispersed throughout Indonesia and several chapters. Meanwhile, PI is an organization that expresses its position and philosophy firmly, based on a knowledge of nationalism transcending ethnic, religious, racial, and regional barriers. In 1923, the PI program sought to attain Indonesian independence via all Indonesian groups and classes' combined efforts without relying on the Dutch (Kahin, 2013).

The concept of nationalism initiated by Hatta, which was discussed comprehensively in accordance with the context of the era of the movement, was described in the form of an article in 1932, in which there were three kinds of nationalism:

"Nationalism varies in appearance and color, depending on the group that advances them. There are three groups of nationalism: the aristocrat (cap ningrat), the intellectuals (cap intelek), and the people (cap rakyat). The world's history demonstrates conclusively that these three groups exist and have always existed." (1976, Hatta). 
What Hatta meant by nationalism at that time was the same as nationalism today. The three ideologies of nationalism are the nationalism of the aristocrat (cap ningrat), the intellectuals (cap intelek), and the people (cap rakyat).

According to Hatta, nationalism's essence is not simply a weapon for liberating the nation from colonialism but also for instilling awareness and conviction in society in order for it to be truly free from colonialism. Hatta views nationalism as a humanitarian philosophy that prioritizes education on the people's consciousness as a whole over all else (Gerald Jacob Tampi, 2015).

As a result of this perspective, Hatta believes that education and public awareness are the primary forces working to end colonialism. As a continuation of the PI concept, the Indonesian National Education movement (PNI Baru) reflects the people's education and awareness. Although not a party, the New PNI's emergence in 1931 contributed significantly to fulfilling Indonesia's national ideals. As is well known, during the start of the Indonesian people's movement, most Indonesians gathered in a party because it had a political meaning and was in direct contact with government activity. For example, SI began as a trading organization (SDI in 1905), evolved into a national-scale Islamic social organization called SI (Sarekat Islam in 1912), and eventually morphed into the Sarekat Islam party (PSI) in 1920. In 1920, the PNI (Indonesian National Party) was founded under Soekarno's authority. After disbanding in 1931, it was renamed Partindo (Indonesian Party). There is a specific reason why the organization that Hatta wanted was called education, not a party. Hatta explained this clearly through an essay published in Daulat Rakyat 1932 as follows:

"Our organization, the people, is the sovereign of the people, named "Indonesian national education." Education! Not or not yet a party. Not because of a mistake or suspicion that the name "education" was taken, but on purpose. People who do not understand laugh at our associations as "schools." Well, we will not be discouraged or angry. Indeed, we want to "go to school" first, go to school to form mind and character, go to school to strengthen faith. It turned out in recent history that mind, character, and faith are the most necessary for our movement (Hatta, 1932).

Hatta desired to use nationalism as a criterion for Indonesia's independence while still depending on the people's strength and dignity via a non-party institution, the Indonesian National Education (PNI). His dissatisfaction with the PNI, as expressed by Soekarno and his associates, was one of the reasons he desired an institution in the shape of civil society with educational aspects. Hatta envisioned the PNI, founded in Bandung in 1927, as a nationalist party dedicated to the cause of Indonesian independence. However, destiny decreed otherwise due to the colonial government's specific surveillance of the PNI authorities and the arrest of Soekarno (together with Gatot Mangunpraja, Maskun, and Supriadinata), the public's trust in the PNI eroded.

Hatta alleges that the entire Dutch East Indies police corps was mobilized to attack the "popular People” party (Deliar, Noer, 1990). Hatta's defense of Sukarno's PNI did not necessarily agree with the following steps taken by the PNI, who wanted a reorganization of the party, which would later turn into Partindo, which was born on May 1, 1931. Hatta preferred that the PNI continue its struggles even without Sukarno. He emphatically said: 
"Ladies and gentlemen of PNI members, you work tirelessly to elevate our party's degree and glory, to penetrate all alleyways and villages in order to make our party proud and to promote our truth. Please invite your friends to join our party so that the PNI can spread its wings throughout Indonesia after a brief period of strengthening. With the power of belief, plainly communicate our reality to the public. Bear in mind, brethren! If our party is stronger, it will be more difficult for people to pounce on us, it will be more difficult for people to beat us up, and it will take longer than what occurred on December 29 last year. As a result, work diligently to strengthen the ranks of our movement" (Hatta, 1930).

Hatta conveyed the expression above to his fellows, PNI administrators, after the downturn that befell their leadership so that they would continue to be enthusiastic about continuing the holy struggle to liberate the Indonesian nation. However, this suggestion was ignored by other PNI officials, especially Sartono, who, on April 25, 1931, dissolved the PNI at the extraordinary congress. Hatta was disappointed with the decision.

"I think the disbandment of the PNI is shameful, and this act weakens the people's movement" (Hatta, 1976).

Hatta was dissatisfied with Sartono's conduct, which put personal gain ahead of the common good. Hatta appears to be more pro-independent parties that are not submissive and do not follow Sartono's Indonesian Party (Partindo). Sujadi, Murad, Kantatmaka, Bondan, Sukarto, Teguh, and others, including Hatta, were among those who claimed to be autonomous groupings.

Hatta's disappointment reached a turning point when the PNI was dissolved without considering the ramifications for the Indonesian people as a whole, who still required a nationalist struggle against the government. Thus, Hatta's New PNI (Indonesian National Education) became an alternative movement, ensuring that the relay of the Indonesian people's liberation struggle did not come to a halt in the midst of the road. Hatta's concepts of nationality were expressed in the New PNI as organizational ideals, philosophies, and principles that the Indonesian people were required to embrace. As previously said, the PNI Baru was founded on two principles: democracy and nationality. These two tenets were the cornerstones of Mohammad Hatta's nationalist thought.

Aristocratic nationalism is held by those who are adamant that an independent Indonesia will be led and ruled by its own people in the future. Aristocrat can be translated as Prijaji, a class in traditional Javanese society that distinguished the elite from the masses or nobles. According to Hatta, the nobles are people who have always filled and aided the government throughout history. Unsurprisingly, nobles or prijaji have always dominated government throughout history, as these groups enjoy legitimacy through their ties to the Dutch East Indies' aristocrats. The Dutch East Indies government felt that feudalism and imperialism could coexist harmoniously in the presence of Indigenous people from the Prijaji circles.

According to Kuntowijoyo (Kuntowijoyo, 1991), the Prijaji were the dominating socioeconomic class at the turn of the twentieth century. According to him, the prjaji or nobles were educated individuals who practiced an open profession at the time. There are those who work for the government, referred to as Ambtenaar, and those who work for the private sector, such as doctors and lawyers, who are referred to as professional intelligentsia. According to him, the first category consists of 
nobles with the rank of high-level nobles, while the second category consists of lower-level nobles. The aristocrats have gathered the strength to carry out noble actions or some Prijaji association with specific purposes.

In 1904, for example, Kuntowijoyo continued, a nobles' association named Abipraya was organized in Surakarta, which pioneered the Javanese cultural movement. Their mission is to advance the Javanese people, also known as the "Kemajenganipun Jawi Nation." This organization is reasonably well-established in terms of management, publication, and meeting facilities. Budi Utomo, a polycentric organization, created four years later, was founded. The Abipraya nobles progressively grew closer to Budi Utomo as a national-political force with expanded bounds encompassing Sunda, Madura, and Java. Budi Utomo was initially pioneered by youth but was eventually taken over by the Prijaji. Hatta identified this group of aristocrats as a manifestation of the nationalism style that was emerging at the time, prioritizing the interests of their own groups.

"When the aristocrats speak of an independent Indonesia, they have seen an Indonesian state that is free of the Dutch's restraints, but Indonesia has moved to become subservient to their control. They establish a national standard for their particular group. The aristocracy has remained the ruling class since time immemorial. When Indonesian territories were administered by their own kings, they became foundations of authoritarianism and feudalism. They are also the Dutch government while the Netherlands is in power here. The Dutch recognized that it was easier to manage the Indonesian people through the "Inlandschehoofden" of their own country's heads of state. Thus, the nobles have a long history of ruling! As a result, it is ingrained in their conscience that they will control Indonesia once it achieves independence. They believe that they have a historical right, dubbed historic recht, over the Indonesian government. That is why they have long aspired to the Majapahit kingdom's restoration to this Indonesian country. Many persons are uncounted for in such a nationality. Only the aristocrat or nobles became the nation's yardstick!" (1976, Hatta).

The aristocrats had the historical authority to fill the government when Indonesia obtained its independence, and they put aside the fate of the people. This fact was not in accordance with the condition of the Indonesian country, which at that time was dominated by the misery of the people, the pain of the people, and the aspiration of the people. The aristocrats had a legacy of forging tight relationships with the Dutch East Indies government, known as the cooperative approach, which Hatta firmly opposed. Hatta felt that Indonesia's independence would be won in a non-cooperative method, believing in the nation's might. For Hatta, non-cooperation meant, among other things, refusing to sit on the "representative" councils constituted by the colonial parties, both at the center and at the regions (Deliar Noer, 1990). (Deliar Noer, 1990). Hatta declared emphatically that non-cooperation also meant refusing to work in official circles as the nobles did. In 1938, Hatta criticized intellectuals with the title "Must be polite in criticism," published in the weekly Adil. The criticism is more or less as follows:

"Criticizing the attitudes of Indonesian intellectuals is not new. People have repeatedly proved that the most highly intelligent people are only concerned about their own affairs, live happily, and have high incomes. Not only from the field of the people's movement came such reproaches, 
but also from the side of the intellectuals themselves, who engaged the movement" (Deliar Noer, 1990). (Deliar Noer, 1990).

This was revealed by Hatta when he witnessed the condition of the homeland, which was still imprisoned with the people's suffering even though some of the intellectuals who excelled in foreign schools such as the Netherlands had returned to their homeland. There is no fundamental change even though the Indigenous people already have several scholars. Intellectuals tend to be pragmatic and put aside the public interest. Its characteristics are not much different from those of aristocratic label nationalism, which prioritizes their own circles. According to Hatta, these intellectuals think that the people are a tool for creating an independent Indonesia while the reins of its leadership remain under the control of the intellectuals (Deliar Noer, 1990). Hatta elaborated his lengthy criticism in a 1932 brochure.

"Independent Indonesia, according to intellectuals, the educated, or the intelligent, must be selfgoverning. The country will neither grow nor flourish unless highly educated individuals lead it. According to them, people are elected to political positions, not because of their lineage but their inherent characteristics. They recognized that they were not noble by blood but by intellect and prowess. According to their hypothesis, many people are poor, and alpha and are obliged to work long hours every day to survive. As a result, the populace lacks time to contemplate politics and the country's security. As a result, the poor do not need to have a say in national affairs. The people, by their very nature, know how to follow. As a result, intellectuals control the fate of the people and the country's affairs. They appear to regard themselves as mob gods. It is self-evident that humans are nothing more than tools of the intellect under such a mindset. The people are only a means to an end: to expand their influence and power. Thus, when intellectuals discuss nationality, they refer to their own nationality label. Indonesia will be autonomous under the intellectuals' reign; this is their goal. Only the intelligent are the nation's yardstick. This type of nationality is often known as a liberal nationalism" (Hatta, 1932).

This description was published as Hatta's rationale for establishing the New PNI, which promoted a nationalist and populist ideology that pitted all national groups exclude the aristocrats and nobles who were preoccupied with personal issues.

Hatta was a member of the Indonesian intellectual circle, but he was not trapped in a pragmatic state; he refused the Dutch offer to join the Volksraad or become an aristocrat of the Dutch East Indies, but instead prioritized the common interest, namely the welfare of the Indonesian people, through political activities and continued struggle in New PNI. According to him, the primary function of intellectuals is to control society or the state by emphasizing their duty to forecast popular will and light the path that will be taken (Deliar Noer, 1990).

In this regard, nobles and intellectuals are similar; both are preoccupied with personal wants; the populace is not seen as having a significant impact on the development of an independent Indonesia. The distinction between the two is thin, particularly the issue of professionalism. At the turn of the twentieth century, students (prospective national intellectuals) must have been members of the aristocratic class, financially able to support themselves throughout their study period. 
Kuntowijoyo (Kuntowijoyo, 1991) highlights the distinction between the two as a viewpoint on how these two groups should react to colonial invites. This implies that intellectuals whose only objective is to feel comfortable in their chosen field of employment are referred to as idealistic nobles. In contrast, those who are both intellectual and non-intellectual and work for the colonial administration are referred to as realist nobles. This is a critical distinction between the two. As a result of their beliefs, particularly in the spirit of nationalism after Indonesia's independence, the Indonesian people were forced to acquiesce to it as a logical outcome of history.

\section{Cap Rakyat: Nationalism Based on Islam}

Nationalism, which is nearly universally adopted, is the only option to independence from superpower countries with colonial and imperial systems, like Indonesia. If Christianity is the bedrock of nationalism in the west, what about in Indonesia? Is nationalism of the people proposed by Hatta compatible with Islamic teachings? This question cannot be distinguished from the writer's uneasiness following the discovery of multiple references indicating that Mohammad Hatta was a secular nationalist. Whereas Hatta always conducts himself in accordance with Islamic beliefs. Hatta is an obedient, trusting, patient, and unyielding individual. Hatta's attitude, according to Subardjo (Ahmad Subardjo Djoyoadisuryo, 1972), was characterized by a fussy temperament and a strong sense of selfdiscipline, which sprang from his puritanical understanding of Islam. Hatta preferred to demonstrate his Islamic mindset by ordinary action rather than through a movement, propaganda, or other means (symbolic Islam). Nurcholis Madjid, too, thought Hatta's Islamic integrity was quite substantial. Meanwhile, Syafii Maarif (Ahmad Syafii Maarif, 2009) asserts that Bung Hatta is a sincere Muslim in both speech and manner, and his integrity is beyond comparison.

As previously stated, Hatta's initial concept of Cap Rakyat nationalism is built on the spirit of Islam. Hatta believed that the nationalism of people mandated that when Indonesia gained independence, the country must be established on democratic representation. This sovereignty idea serves as the foundation for all types of civilized human beings (Mohammad Hatta, 1976).

According to Anthony D Smith, nationalism must be founded on sacred principles that will sustain nationalism. Religion is one of the holy foundations (Anthony D Smith, 2001). According to him, as long as the nation's sacred foundations endure, secular materialism and individualism will not undermine the fundamental beliefs of a community with a history and destiny, as long as nationalism as a political ideology is destined to flourish, and as long as national identity remains one of the fundamental pillars of the current world order. According to Anthony D Smith, nationalism must be founded on sacred principles that will sustain nationalism. Religion is one of the holy foundations (Anthony D Smith, 2001). According to him, as long as the nation's sacred foundations endure, secular materialism and individualism will not undermine the fundamental beliefs of a community with a history and destiny, as long as nationalism as a political ideology is destined to flourish, and as long as national identity remains one of the fundamental pillars of the contemporary world order.

While Christianity has been used to legitimize nationalism in Western countries, Islam has legitimized the growth of nationalism in Indonesia. This occurs as a result of the complicated nature of nationalist ideas. According to George MC Turnan Kahin (Kahin, 2013), Islam does not simply 
passively absorb the impulses inherent in nationalism. Rather than that, it established the first route for creating modern and mature Indonesian nationalism, a channel that has continued to play a vital role until the present day. All of this is possible because of Islam's distinctive character, which is embraced by over $90 \%$ of Indonesians who believe in it. Kahin views Islam in Indonesia as tolerant, eschewing fundamentalism and radicalism, as is frequently the case in other sections of Islam, particularly the Middle East. That is nationalism developed in the Dutch East Indies because it did not violate Islamic teachings. Even later, when Indonesia was attacked by the Dutch and British again in 1945, the Muslims issued a fatwa declaring patriotism to be an integral component of faith. As a result, we can conclude that the growth of nationalism is aided by an inclusive religious atmosphere.

The relationship between nationalism and religion, particularly Islam in the Indonesian context, did not emerge abruptly and with hegemony in the Indonesian independence movement scene. As previously stated, nationalism was a component of the Dutch East Indies government's political endeavor based on ethnic awareness to oppose colonialism, imperialism, and feudalism. According to Azyumardi Azra (Azra, 2006), nationalism arose in Indonesia due to the amalgamation of ethnic and political passions with religious fervor. Thus, it is unsurprising that nationalism has developed in Indonesia and found a home within the tolerant, peaceful, and inclusive Indonesian Islamic culture. This is also what Azyumardi eventually concluded: Southeast Asian Islam, particularly Indonesian Islam, with its tolerant and pleasant image, stimulated, flourished, and even contributed significantly to the emergence of nationalism. Ahmad Syafii Maarif (Ahmad Syafii Maarif, 2009) stated the same point, stating that there was no doubt that Islam was a significant component of this nation's nationalism at the time, alongside language and historical experience. That is, nationalism began to focus on political, social, and cultural aspects for specific reasons relating to the nation and state's life. However, it gained momentum under the influence of Islam.

According to Abuddin Nata, the relationship between Islam and nationality can be seen in the importance of upholding the universal and eternal values of Islamic teachings, such as truth, justice, compassion, patience, integration, kindness, and beauty, by not being too fixated on formal rules, or by allowing for reinterpretation as long as it adheres to the universal values of Islamic teachings (Abuddin Nata, 2016).

Hatta's religious narrative's concept of nationalism of people (Cap Rakyat) might also be referred to as the narrative of the public interests. The nationalism of people is solely concerned with the benefit of communal living rather than the interests of individual groups, which is in accordance with Islamic teachings, even though Hatta does not explicitly state and explain that the nationalism of the people is an idea that is following Islamic teachings. Deliar Noer once attempted to trace the pre-independence Mohammad Hatta's national and Islamic thoughts in this regard. According to him, around 1930, the concept of nationalism or nationalism and Islam were constantly contested entities. The dispute ended in two fatwas issued by the ulama, the first declaring nationalism to be haraam and the second declaring it to be required in the sense that love for one's homeland is a component of faith. Hatta, he claims, did not convey his opinion explicitly in this regard. It appears as though he was either hesitant or unwilling to become involved in a highly contentious issue at the time. Deliar Noer believes that Hatta's aspiration for nationalism does not clash with Islamic principles. The evidence supporting Deliar's claim is found in Hatta's personality, both a devout Muslim and a nationalist. Even so, Deliar Noer concluded that the evidence was insufficient to establish Hatta's concept of Islamic nationalism as 
legitimate; Hatta's adherence to Islamic teachings was a private matter, while the affairs of the general public (Nationalism) were not; this reasoning was later used by some scholars to conclude that Hatta was a secular nationalist. Hatta wrote the piece while still in the Netherlands, in response to the Round Table Conference between Britain and India, dominated by Muslim nationalists."

"The Indian Congress party should not regard its body as the exclusive representative of all Indians. Moreover, neither should the Indian Muslim unity party (namely, the Indian Muslim League) be ignorant to its Islam. Each of these freedoms, religion, and advancement must be carefully safeguarded. Each organization is free to worship and also to determine how it will be run. Additionally, each community must be free to build its own schools to progress its own civilization” (Hatta, 1931).

Hatta's concern was allegedly prompted by his association with several Indian activists, including Jawaharlal Nehru, who served as administrators of the Tegen Imperialism League, Tegen Koloniale Onderdrukking En Voor Nationale Onafhankelijkheid (League Against Imperialism, Colonial Oppression, and For National Independence) in 1927.

According to Azyumardi (Azra, 2016), from the earliest stages of Islam's development until at least pre-modern times, the Muslim community recognized only two religiopolitical territorial concepts: Dar al-Islam, a peaceful area, namely Muslim territory, and dar al-Harb, a war zone, or non-Muslim territory. Thus, the nation-state notion is fraught with historical and conceptual difficulties. Hatta was fully aware that if his Islamic beliefs at the time were overemphasized in favor of his national spirit, it would spark polemics in a Muslim-majority country.

Throughout the movement time, Hatta stressed caution above religious fervor in his political efforts. After all, Hatta has long maintained a national conversation with various Muslim groups, including Haji Agus Salim, Hos Cokroaminoto, Abdul Manaf (an Egyptian student from Indonesia), and other figures interested in Islamic values. Thus, it is clear that Hatta's concept of nationalism, which is consistent with the Indonesian and Islamic contexts, is the nationalism of people (Cap Rakyat). It is in opposition to Aristocrats (Cap Ningrat) and Intellectual (Cap Intelek) nationalisms in that it places the welfare of the people first. The people are a barometer of the Indonesian nation's highs and lows.

"Because the people are the nation's body and soul. Furthermore, it is the individuals that determine our high and low degrees. We will ascend with the people and descend with the people. The survival or demise of an independent Indonesia is entirely based on the people's spirit. Ideologues and educated people can have meaning if they are surrounded by individuals who are conscious of and concerned about their sovereignty because we can hear a lot of the pulse of the nation's spirit when it is in the hands of the people. The intellectual's role is limited to predicting the people's will and illuminating the path that will progress. If Indonesia gains independence, it must establish a People's Kingdom based on popular will" (Hatta, 1932). Prioritizing the people means prioritizing the ummah, as Islam teaches; yet, the term "people" is used broadly in nationalism of people (Cap Rakyat) to avoid religious fanaticism. 


\section{Conclusions}

Nationalism and Islam are still contentious issues among academicians, historians, and scholars. Both originate in distinct locations; Islam emerged in the seventh century as a religion revealed by Allah to the Prophet Muhammad to guide his ummah in leading a decent and righteous life, whereas nationalism was born in the womb of Western civilization in the eighteenth century. Nationalism is based on an appreciation for the similarity of fate, area, race, and share a common objective. Meanwhile, the author defines nationalism as a nationalism founded on love for the country that shares a common goal: liberation from the shackles of foreign hegemony using the people as the primary force. In the Indonesian context, we can observe a correlation between nationalism and Islam in terms of togetherness and getting to know one another across ethnic groups, groupings, nations, and so on, as outlined in the Qur'an.

Hatta emphasized that nationalism does not have to follow the West's lead, as nationalism was born from the West, which gave birth to the seeds of capitalism, imperialism, and individualism, but that nationalism can be Indonesianized in accordance with Indonesia's nature and culture, which are pluralistic, tolerant, and cooperative, among other characteristics. According to Hatta, nationalism is a widespread belief held by a significant number of people that they are a nation; it is a consciousness of their nationhood. Hatta identified three distinct forms of nationalism that flourished in early twentiethcentury Indonesia: The nationalism of Aristocrats (Cap Ningrat), the nationalism of intellectual (educated people) (Cap Intelek), and the nationalism of people (Cap Rakyat).

According to Hatta, when Indonesia achieves independence, it must strongly adhere to the nationalist principles embodied in the nationalism of people (Cap Rakyat). Under Cap Rakyat nationalism, Indonesian country will be born democratically, with the people holding the ultimate power (people's sovereignty). According to him, the people are the country's and nation's body and soul. Mutual aid, cooperation, and reflection are inherent characteristics of the Indonesian people, who possess enormous potential for achieving a wealthy, just, and prosperous state order consistent with the sublime values of Islamic teachings.

\section{References}

Abbas, Anwar. (2010). Bung Hatta dan Ekonomi Islam. Jakarta: Penerbit Buku Kompas.

Adisusilo, Sutarjo. (2002). Nasionalisme, Demokrasi, Civil Society. Jurnal Iman, Ilmu, Budaya, III, (9): 4.

Alfarizi, Salman. (2012). Mohammad Hatta: Biografi Singkat 1902-1980. Yogyakarta: Garasi.

Anderson, Bennedict (2008). Imagined Communities (Komunitas-komunitas Terbayang). Penerjemah Omi Intan Naomi. Jakarta: Insist Press.

Azra, Azyumardi. (2006). Renaisans Islam Asia Tenggara: Sejarah dan Kekuasaan.

Bandung: Remaja Rosdakarya. 
Azra, Azyumardi, (2003). Surau: Pendidikan Islam Tradisional dalam Transisi dan Modernisasi. Jakarta: Logos Wacana Ilmu.

Azra, Azyumardi, (2016). Transformasi Politik Islam: Radikalisme, Khilafatisme dan Demokrasi. Jakarta: Prenada Media Group.

Djoyoadisuryo, Ahmad Subardjo. (1972). "Kenang-Kenangan Akan Saudara Mohammad Hatta” dalam Mohammad Hatta, Bung Hatta Mengabdi Pada Cita-Cita Perjuangan Bangsa. Jakarta : T.pn.

Hatta, Mohammad. (1976). Kumpulan Karangan I. Jakarta: Bulan Bintang.

Hatta, Mohammad, (1979). Memoir. Jakarta: Tintamas.

Hatta, Mohammad, Asas PI 1924.

Hatta, Mohammad,-Catatan-Catatan Rapat PI 1924-1925.

Hatta, Mohammad,Kearah Indonesia Merdeka. Brosur 1932.

Hatta, Mohammad, “PNI Mendapat Percobaan,” Persatuan Indonesia. 1930.

Hp, Suradi. dkk. (1986). Sejarah Pemikiran Pendidkan dan Kebudayaan. Jakarta: Ditjarahnitra Ditjen Kebudayaan Depdikbud.

Kahin, George McTurnan. (2013). Nasionalisme dan Revolusi Indonesia. Penerjemah Tim Komunitas Bambu. Depok: Komunitas Bambu.

Kartodirdjo, Sartono. (1972) .Kolonialisme dan Nasionalisme di Indonesia pada Abad-19 dan Abad20. Dalam Seksi Penelitian, Jurusan Sejarah, Fakultas Sastra dan Kebudayaan, Universitas Gadjah Mada.

Kohn, Hans. (1976). Nasionalisme, Arti dan Sejarahnya. Jakarta: PT. Pembangunan.

Kuntowijoyo. (1991). Paradigma Islam: Interpretasi untuk Aksi. Bandung: PT Mizan Pustaka.

Ma’arif, Ahmad Syafii. (2009). Islam KeIndonesiaan dan Kemanusiaan: Sebuah Refleksi Sejarah. Bandung: Mizan.

Ma'arif, Ahmad Syafii. (2009). Islam dalam Bingkai KeIndonesiaan dan Kemanusiaan: Sebuah Refleksi Sejarah. Bandung: Mizan.

Madjid, Nurcholis. (2003). Indonesia Kita. Jakarta: Gramedia Pustaka Utama.

Majid, Abdul dan Swasono, Sri-Edi. (1988). Wawasan Ekonomi Pancasila. Jakarta: UI Press.

Nata, Abuddin. (2016). Islam dan Kebangsaan, Makalah disampaikan dalam Pengenalan Budaya Akademik dan Kurikulum (PBAK) Fakultas Tarbiyah dan Keguruan, UIN Jakarta.

Narwoko, J Dwi, dan Suyanto, Bagong, ed. (2015).Sosiologi: Teks Pengantar dan Terapan. Jakarta: Prenada Media Group. 
Noer, Deliar. (1990). Mohammad Hatta: Biografi Politik. Jakarta: LP3ES.

Rasyad, Zubir. (2009). Ranah dan Adat Minangkabau. Jakarta: Agra Wirasanda.

Subchi, Imam. (2012). Pengantar Antropologi. Ciputat: Mumtaza Islamic School Press.

Subhan, Arif. (2009). Lembaga Pendidkan Islam Indonesia Abad ke-20. Smith, Anthony D (2001). Nasionalisme: Teori, Ideologi, Sejarah. Penerjemah Frans Kowa. Jakarta: Penerbit Erlangga.

Tampi, Gerald Jacob (2015). Nasionalisme Sukarno dan Nasionalisme Hatta: Suatu Studi Perbandingan Mengenai Konsep Nasionalisme menurut Sukarno dan Hatta. Tesis, Magister Sosiologi Agama Fakultas Teologi, Universitas Kristen Satya Wacana Salatiga. 